\title{
Review \\ Application of Upstream Open Reading Frames (uORFs) Editing for the Development of Stress-Tolerant Crops
}

\author{
Taeyoung Um ${ }^{1}$, Taehyeon Park ${ }^{2}$, Jae Sung Shim ${ }^{3}$, Youn Shic Kim ${ }^{1}$, Gang-Seob Lee ${ }^{4}$, Ik-Young Choi ${ }^{5}$, \\ Ju-Kon Kim ${ }^{2}$, Jun Sung Seo ${ }^{2, *}$ and Soo Chul Park ${ }^{4, *}$
}

1 Agriculture and Life Sciences Research Institute, Kangwon National University, Chuncheon 24341, Korea; tyoungum@kangwon.ac.kr (T.U.); younshic@kangwon.ac.kr (Y.S.K.)

2 Crop Biotechnology Institute, GreenBio Science and Technology, Seoul National University, Pyeongchang 25354, Korea; qkrxogus95@snu.ac.kr (T.P.); jukon@snu.ac.kr (J.-K.K.)

3 School of Biological Sciences and Technology, Chonnam National University, Gwangju 61186, Korea; jsshim@chonnam.ac.kr

4 Department of Agricultural Biotechnology, National Academy of Agricultural Science, Rural Development Administration, Jeonju 54874, Korea; kangslee@korea.kr

5 Department of Agricultural and Life Industry, Kangwon National University, Chuncheon 24341, Korea; choii@kangwon.ac.kr

* $\quad$ Correspondence: xfiles96@snu.ac.kr (J.S.S.); usdapark@korea.kr (S.C.P.); Tel.: +82-33-339-5826 (J.S.S.); $+82-63-238-4584$ (S.C.P.)

Citation: Um, T.; Park, T.; Shim, J.S.; Kim, Y.S.; Lee, G.-S.; Choi, I.-Y.; Kim, J.-K.; Seo, J.S.; Park, S.C. Application of Upstream Open Reading Frames (uORFs) Editing for the Development of Stress-Tolerant Crops. Int. J. Mol. Sci. 2021, 22, 3743. https://doi.org/ $10.3390 /$ ijms 22073743

Academic Editor: Kenji Miura

Received: 24 February 2021

Accepted: 31 March 2021

Published: 3 April 2021

Publisher's Note: MDPI stays neutral with regard to jurisdictional claims in published maps and institutional affiliations.

Copyright: (c) 2021 by the authors. Licensee MDPI, Basel, Switzerland. This article is an open access article distributed under the terms and conditions of the Creative Commons Attribution (CC BY) license (https:/ / creativecommons.org/licenses/by/ $4.0 /)$.
Abstract: Global population growth and climate change are posing increasing challenges to the production of a stable crop supply using current agricultural practices. The generation of genetically modified (GM) crops has contributed to improving crop stress tolerance and productivity; however, many regulations are still in place that limit their commercialization. Recently, alternative biotechnology-based strategies, such as gene-edited (GE) crops, have been in the spotlight. Gene-editing technology, based on the clustered regularly interspaced short palindromic repeats (CRISPR) platform, has emerged as a revolutionary tool for targeted gene mutation, and has received attention as a game changer in the global biotechnology market. Here, we briefly introduce the concept of upstream open reading frames (uORFs) editing, which allows for control of the translation of downstream ORFs, and outline the potential for enhancing target gene expression by mutating uORFs. We discuss the current status of developing stress-tolerant crops, and discuss uORF targets associated with salt stress-responsive genes in rice that have already been verified by transgenic research. Finally, we overview the strategy for developing GE crops using uORF editing via the CRISPR-Cas9 system. A case is therefore made that the mutation of uORFs represents an efficient method for developing GE crops and an expansion of the scope of application of genome editing technology.

Keywords: upstream open reading frames (uORFs); stress-resistant crops; gene editing; CRISPR; enhancing the gene expression

\section{Introduction}

Crop productivity is increasingly threatened by climate change, and this issue is exacerbated by the growing global population. For example, climate change is causing environmental stress, as exemplified by elevated temperatures, drought, and flooding. On the other hand, global population growth and urbanization has resulted in the loss of agriculturally viable land. According to a study of the correlation between crop yields and global warming, an increase of 1 degree Celsius in global temperatures could result in a reduction of the global production of wheat by $6.0 \%$, rice (Oryza sativa) by $3.2 \%$, corn (Zea mays) by $7.4 \%$, and soybeans (Glycine max) by 3.1\% [1]. Additionally, it is expected that the global population will reach almost 9 billion by 2050, and the expansion of urbanization will result in an $80 \%$ loss of agricultural land by 2030 in Asia and Africa. Consequently, an 
increase of more than $70 \%$ of current crop production will be required to maintain food security [2-4].

Genetically modified (GM) crops provide a strategy to increase stress resistance and crop productivity through genetic improvement in relatively short time frames compared to traditional breeding approaches [5]. Furthermore, their generation can enhance the understanding of molecular mechanisms that affect plant development and defense, and this information has provided opportunities to improve crop yield [6-8]. However, regulatory hurdles for GM crop commercialization, including safety evaluation, have necessitated the development of alternative strategies involving gene-editing (GE), such as the use of zinc-finger nucleases (ZFNs), TAL effector nucleases (TALENs), and clustered regularly interspaced short palindromic repeats (CRISPR) tools [9]. As an example, Calyxt has developed a TALEN-based genome-edited soybean with modified oil composition and commercialized the derived product, high oleic soybean oil, on the US market [10]. In contrast to the previous GM techniques, which randomly introduce changes, GE allows for precise modification and is identical to those derived from conventional breeding [11,12]. Thus, it is anticipated that many GE crops could be a more acceptable product than GM crops [13].

Messenger RNA (mRNA) is a transcript of the gene, and generally composed of an untranslated region (UTR and intron) and a translated coding region (exon). Upstream open reading frames (uORFs) are a cis-element in the $5^{\prime}$ untranslated regions (UTRs) of mRNAs that induce ribosome stalling and dissociation during the translation of mRNAs [14,15]. Most uORFs negatively regulate the expression of protein encoding main ORF (mORF) of mRNA (Figure 1A). During the translation process, the uORF in the $5^{\prime} \mathrm{UTR}$ is translated to short peptides, and most uORFs have a start codon (AUG), although some exceptions have been identified $[14,16]$. It has been predicted by sequence analysis that $49 \%$ and $44 \%$ of the total transcripts of humans and mice, respectively, have uORFs, as have $20 \% \sim 40 \%$ of the total transcripts of plants such as rice, Arabidopsis thaliana, and corn [17,18]. Most stressresponsive transcripts harboring $\mathrm{uORF}$ are induced by specific environmental conditions, and it is known that mutations of $\mathrm{UORF}$ sequences reduce their capacity for negative regulation $[19,20]$.

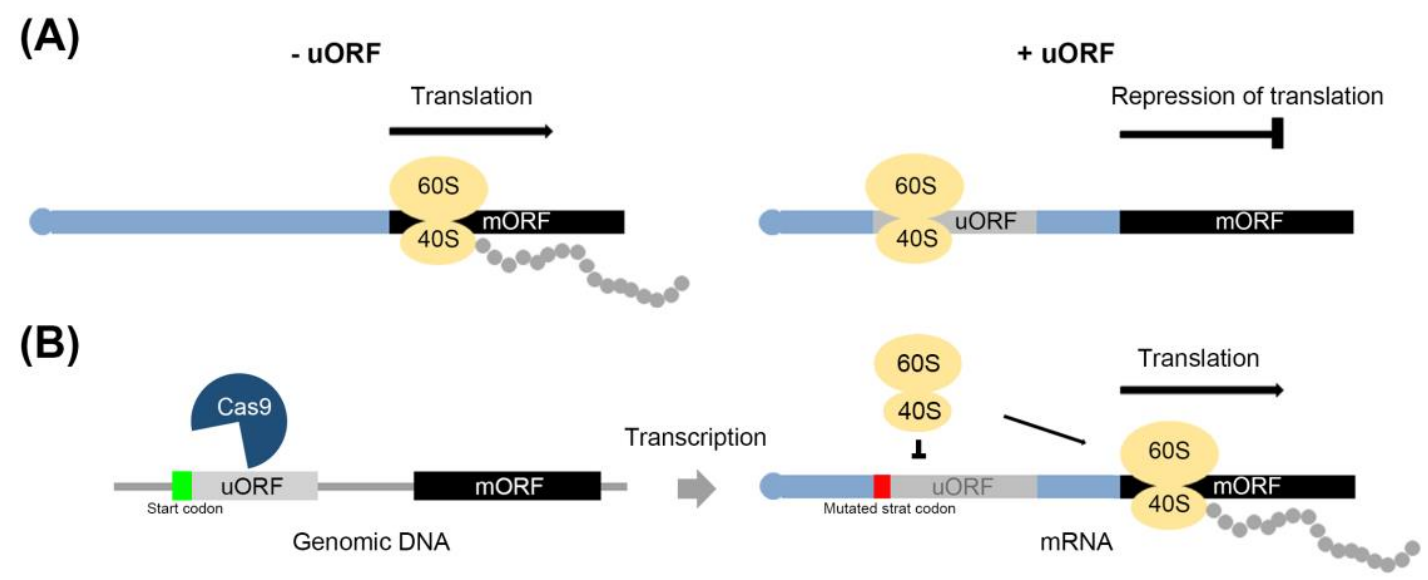

Figure 1. Overview of CRISPR-Cas9-mediated regulation of the repression of translation, as discussed in this review. (A) The mRNA (black rectangle) with uORF (gray rectangle) induces ribosome (yellow ovals) stalling in the uORF, which represses translation of the main ORF (mORF). Polypeptide: gray circle. (B) Mutation of the start codon region (green or red rectangle) in uORF using CRISPR-Cas9 inhibits ribosome stalling, leading to induced translation of mORF.

This review describes the strategic application of uORF sequences for developing salt stress-tolerant crops, focusing on the enhancement of the target gene expression by the mutation of uORF using CRISPR-Cas9 (Figure 1B), and discusses a general approach for developing GE crops using uORF editing. 


\section{Upstream Open Reading Frames (uORF)}

\subsection{The Process of Translation of $m R N A$ Mediated by $u O R F$}

During mRNA translation, $\mathrm{UORF}$ translation causes ribosome stalling, leading to repressed translation of the mORF. This process can be divided into three stages: initiation, elongation, and termination [15,21-24]. First, the start codon in uORF is recognized by scanning the $40 \mathrm{~S}$ ribosomal subunit and eukaryotic initiation factors (eIFs), then, in the second stage, the $60 \mathrm{~S}$ and $80 \mathrm{~S}$ ribosomal complexes bind to the $40 \mathrm{~S}$, allowing for the elongation of the polypeptide chain. Finally, the third stage involves the termination of translation in the uORF, which results in repressed translation of the mORF (Figure 2A). The detailed process can be described in the following steps: (1) ribosome stalling, physical interaction between the peptide encoded by the uORF and ribosomes; (2) the translational machinery dissociates from the mRNA after UORF translation and the mORF is not translated; (3) trigger mRNA decay, nonsense-mediated mRNA decay (NMD) is induced due to the presence of the stop codons in UORF and the recognition as premature transcript; and (4) decreasing mORF translation, after $\mathrm{UORF}$ translation elongation, the $40 \mathrm{~S}$ and $60 \mathrm{~S}$ dissociate from the uORF, and the $40 \mathrm{~S}$ unit remains associated with the mRNA. Translation of the MORF is then re-initiated.

\section{(A)}

Ribosome stalling
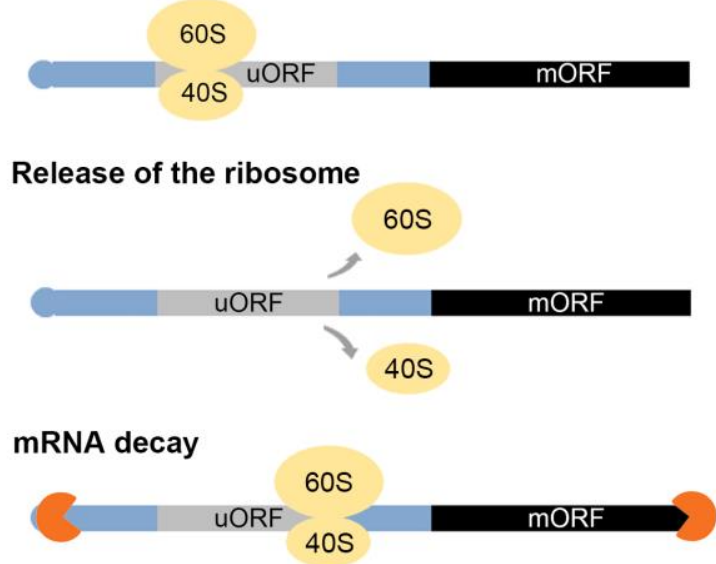

Re-translation of $40 \mathrm{~S}$

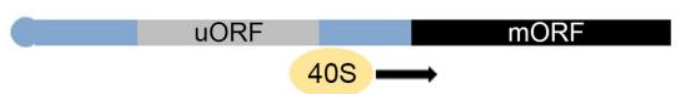

(B)

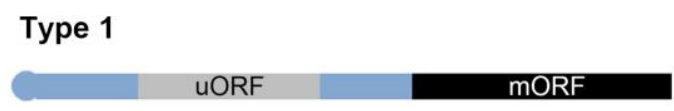

Type 3

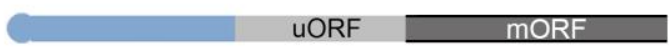

Multi-type

UORF UORF UORF MORF

Figure 2. Regulation of uORF-mediated translation and types of uORF. (A) The various mechanism of translational repression. (B) Types of uORFs. uORFs are classified multiple type and type 1-3. Blue, gray and black rectangles indicate regions of the mRNA, yellow ovals indicate the ribosome complex, and orange circles indicate the exosome.

\subsection{The Classification of $u O R F$}

The uORFs are classified by the position of the uORF stop codon [25]. Type 1: the location of the stop codon of the uORF is independent of the mORF. Type 2: the stop codon of the uORF overlaps with the mORF. Type 3: the stop codon of the uORF is the same as that of the stop codon of the mORF (Figure 2B). In rice, it was expected that $\mathrm{uORF}$ containing genes are $20.65 \%$ of the total genes. Type 1 and Type 2 account for $87.63 \%$ and $12.17 \%$ of the total uORFs, respectively, and there are only 41 examples of Type 3 uORFs [18,25]. 


\subsection{Stress-Responsive uORF-Mediated Transcripts in Rice}

Drought and the salinization of soils are accelerated by climate change and lead to a significant reduction in crop yield $[26,27]$. These environmental phenomena cause cellular dehydration by reducing the water content of the cytoplasm, leading to substantial physiological and cytological changes [28-30]. To survive under such stressful conditions, plants have developed a range of mechanisms to reduce the effects of drought stress, many of which are associated with extensive changes in gene expression [31,32]. Notably, it was reported that most stress-responsive transcripts harbor uORFs in plants [21,25]. Rice is an excellent model to study the significance of uORFs in stress-related gene expression since its genome has been extensively characterized, it is a major crop, and it is sensitive to drought and salt stress $[33,34]$. As part of a mechanism associated with salt stress, members of the chloride channel protein (CLC) family, which is found in prokaryotes and eukaryotes, play an important role in ion homeostasis $[35,36]$. A characterized example in rice is the OsCLC1 protein, which is located at the tonoplast in the cell [37], and overexpression of OsCLC1 in rice was found to enhance drought stress tolerance through modulating jasmonic acid (JA) signaling [38]. We predicted the uORF in OsCLC1 transcripts using uORFFlight (http:/ / uorflight.whu.edu.cn accessed on 20 February 2021) and identified a type $1 \mathrm{uORF}$ in the $5^{\prime} \mathrm{UTR}$. The uORF is comprised of 33 nucleotides, including the start codon (ATG) and stop codon (TGG). We also analyzed the uORFs in the 5'UTRs of the salt stress-responsive rice genes (Table 1) through the identification of 107 salt stress-responsive genes reported in the literature, and predicted $393 \mathrm{uORF}$ in the 46 transcripts related to the transporter, transcription factor, and kinase functional categories. Of these, type $1 \mathrm{uORFs}$ accounted for $91 \%$, while only $8.7 \%$ were of type 2 , and type 3 uORFs were not represented.

\subsection{Avoidance of uORF-Mediated Repression of Gene Expression during Stress Responses}

Under stressful conditions, plants activate their defense systems and limit their growth, which is associated with resource restrictions $[39,40]$. The interaction between defense and growth mechanisms in plants involves in a well-documented tradeoff system. Antagonistic interactions between JA- and gibberellic acid (GA)-regulated processes are one of the cases [41-43]. uORF-mediated translational control represents another instance of a tradeoff system. For example, the expression of uORF-associated transcripts is down-regulated by $\mathrm{uORF}$ translation under normal conditions to facilitate plant growth. To upregulate their expression under stress conditions, strategies are employed to avoid uORF-mediated translation. These include leaky scanning of the $\mathrm{UORF}$ and the reinitiation of the translation process, and the alternative splicing and selection of the transcription start site during the transcription process [14,43-47]. (1) Leaky scanning of uORF: 40S ribosome subunits initiate the translation on the mRNA 5' cap and recognize the $\mathrm{UORF}$ before the mORF (Figure 1A). Unlike regular scanning, 40S ribosome subunits do not scan the uORF start codon, and recognize the mORF start codon through leaky scanning. (2) Reinitiation of translation: After translation of the $\mathrm{uORF}$, the $60 \mathrm{~S}$ ribosome subunits are released, and only $40 \mathrm{~S}$ ribosome subunits bind to the MORF (Figure 2A). When mORF translation is required, the remaining $40 \mathrm{~S}$ ribosome subunits in mRNA recognize the mORF start codon and associate with the $60 \mathrm{~S}$ subunits again. (3) Alternative slicing: the UORF start codon or uORF sequences in the intron are removed by the splicing of pre-mRNA. The transcript without the $\mathrm{uORF}$ is generated from pre-mRNA (Figure 3A). (4) Selection of the transcription start sites: the transcripts of numerous genes are determined by multiple transcription start sites (TSSs). Under normal conditions, transcripts with a uORF are produced from TSSs located upstream of the $\mathrm{uORF}$, whereas under stress conditions, transcripts without a uORF are produced from TSSs located downstream of the uORF (Figure 3B). 
Table 1. Analysis of uORF in salt stress responsive genes.

\begin{tabular}{|c|c|c|c|c|c|c|c|}
\hline \multirow{2}{*}{ Gene } & \multirow{2}{*}{$\begin{array}{l}\text { Gene ID } \\
\text { (Rap-DB) }\end{array}$} & \multirow{2}{*}{$\begin{array}{c}\text { Transcript ID } \\
\text { (MSU) }\end{array}$} & \multicolumn{3}{|c|}{ uORF Type } & \multirow{2}{*}{$\begin{array}{c}\text { Expression } \\
\text { Response }\end{array}$} & \multirow{2}{*}{ Reference } \\
\hline & & & 1 & 2 & 3 & & \\
\hline \multirow{2}{*}{$H A K 1$} & \multirow{2}{*}{ Os04g0401700 } & LOC_Os04g32920.2 & 1 & 0 & 0 & \multirow{2}{*}{ down } & \multirow[b]{2}{*}[48]{} \\
\hline & & LOC_Os04g32920.4 & 4 & 0 & 0 & & \\
\hline HAK10 & Os06g0625900 & LOC_Os06g42030.1 & 1 & 0 & 0 & up & [49] \\
\hline \multirow{3}{*}{ HKT4 } & \multirow{3}{*}{ Os04g0607500 } & LOC_Os04g51820.1 & 2 & 0 & 0 & \multirow{3}{*}{ up } & \multirow{3}{*}[49]{} \\
\hline & & LOC_Os04g51820.2 & 2 & 0 & 0 & & \\
\hline & & LOC_Os04g51820.3 & 3 & 12 & 0 & & \\
\hline HKT6 & Os02g0175000 & LOC_Os02g07830.1 & 2 & 1 & 0 & down & [49] \\
\hline HKT8 & Os01g0307500 & LOC_Os01g20160.1 & 1 & 0 & 0 & down & [49] \\
\hline \multirow{3}{*}{ NHX1 } & \multirow{3}{*}{ Os07g0666900 } & LOC_Os07g47100.1 & 1 & 0 & 0 & \multirow{3}{*}{ up } & \multirow{3}{*}[50]{} \\
\hline & & LOC_Os07g47100.2 & 1 & 0 & 0 & & \\
\hline & & LOC_Os07g47100.3 & 1 & 0 & 0 & & \\
\hline \multirow{4}{*}{ SOS1 } & \multirow{4}{*}{ Os12g0641100 } & LOC_Os12g44360.1 & 9 & 3 & 0 & \multirow{4}{*}{ up } & \multirow{4}{*}[50]{} \\
\hline & & LOC_Os12g44360.2 & 0 & 1 & 0 & & \\
\hline & & LOC_Os12g44360.3 & 0 & 1 & 0 & & \\
\hline & & LOC_Os12g44360.4 & 0 & 1 & 0 & & \\
\hline \multirow[b]{2}{*}{ CAX3 } & \multirow[b]{2}{*}{ Os04g0653200 } & LOC_Os04g55940.1 & 2 & 0 & 0 & \multirow{2}{*}{ up } & \\
\hline & & LOC_Os04g55940.2 & 1 & 0 & 0 & & [51] \\
\hline & & LOC_Os03g60430.1 & 2 & 0 & 0 & & \\
\hline IDS1 & Os03g0818800 & LOC_Os03g60430.2 & 2 & 0 & 0 & down & [52] \\
\hline & & LOC_Os01g66120.1 & 1 & 0 & 0 & & \\
\hline NAC6 & Os01g0884300 & LOC_Os01g66120.2 & 3 & 0 & 0 & up & [53] \\
\hline & & LOC_Os07g48630.1 & 1 & 0 & 0 & & \\
\hline EIL2 & Os07g0685700 & LOC_Os07g48630.2 & 12 & 0 & 0 & down & [54] \\
\hline & & LOC_Os01g06640.1 & 3 & 0 & 0 & & \\
\hline bHLH035 & Os01g0159800 & LOC_Os01g06640.2 & 2 & 0 & 0 & up & [55] \\
\hline & & LOC_Os01g06640.3 & 14 & 0 & 0 & & \\
\hline LEA5 & Os05g0584200 & LOC_Os05g50710.1 & 1 & 0 & 0 & up & [56] \\
\hline JAZ9 & Os03g0180800 & LOC_Os03g08310.1 & 1 & 0 & 0 & down & [57] \\
\hline RSS3 & Os11g0446000 & LOC_Os03g08310.1 & 1 & 0 & 0 & up & [58] \\
\hline$A C A 6$ & Os01g0939100 & LOC_Os01g71240.1 & 3 & 0 & 0 & up & [59] \\
\hline RLCK3 & Os01g0113300 & LOC_Os01g02300.1 & 1 & 0 & 0 & up & {$[60]$} \\
\hline & & LOC_Os01g02390.1 & 0 & 1 & 0 & un & \\
\hline RLCK5 & Os01g0114100 & LOC_Os01g02390.2 & 0 & 1 & 0 & up & [60] \\
\hline & & LOC_Os01g02400.1 & 0 & 0 & 0 & & \\
\hline RLCK6 & Os01g0114300 & LOC_Os01g02400.2 & 17 & 1 & 0 & up & [60] \\
\hline & & LOC_Os01g02400.3 & 39 & 0 & 0 & & \\
\hline$R L C K 27$ & Os01g0247500 & LOC_Os01g14510.1 & 8 & 0 & 0 & up & {$[60]$} \\
\hline & & LOC_Os01g41870.1 & 1 & 0 & 0 & & \\
\hline RLCK42 & Os01g0602800 & LOC_Os01g41870.2 & 1 & 0 & 0 & down & [60] \\
\hline
\end{tabular}


Table 1. Cont.

\begin{tabular}{|c|c|c|c|c|c|c|c|}
\hline \multirow{2}{*}{ Gene } & \multirow{2}{*}{$\begin{array}{l}\text { Gene ID } \\
\text { (Rap-DB) }\end{array}$} & \multirow{2}{*}{$\begin{array}{c}\text { Transcript ID } \\
\text { (MSU) }\end{array}$} & \multicolumn{3}{|c|}{ uORF Type } & \multirow{2}{*}{$\begin{array}{l}\text { Expression } \\
\text { Response }\end{array}$} & \multirow{2}{*}{ Reference } \\
\hline & & & 1 & 2 & 3 & & \\
\hline \multirow{3}{*}{$R L C K 48$} & \multirow{3}{*}{ Os01g0852100 } & LOC_Os01g63280.1 & 20 & 3 & 0 & \multirow{3}{*}{ down } & \multirow{3}{*}[60]{} \\
\hline & & LOC_Os01g63280.2 & 1 & 1 & 0 & & \\
\hline & & LOC_Os01g63280.3 & 14 & 3 & 0 & & \\
\hline RLCK57 & Os01g0973500 & LOC_Os01g74200.1 & 1 & 0 & 0 & up & [60] \\
\hline$R L C K 72$ & Os02g0513000 & LOC_Os02g30900.1 & 2 & 0 & 0 & up & {$[60]$} \\
\hline$R L C K 80$ & Os02g0650500 & LOC_Os02g43430.1 & 1 & 0 & 0 & up & {$[60]$} \\
\hline \multirow{2}{*}{$\begin{array}{l}\text { RLCK85 } \\
\quad(E R 2)\end{array}$} & \multirow[b]{2}{*}{ Os02g0777400 } & LOC_Os02g53720.1 & 1 & 0 & 0 & \multirow{2}{*}{ down } & \multirow[b]{2}{*}[60]{} \\
\hline & & LOC_Os02g53720.2 & 1 & 0 & 0 & & \\
\hline RLCK95 & Os03g0113000 & LOC_Os03g02190.1 & 0 & 1 & 0 & down & [60] \\
\hline $\begin{array}{c}\text { RLCK101 } \\
\text { (PTK3) }\end{array}$ & Os03g0159100 & LOC_Os03g06330.1 & 9 & 0 & 0 & up & {$[60]$} \\
\hline \multirow{3}{*}{ RLCK106 } & \multirow{3}{*}{ Os03g0264300 } & LOC_Os03g15770.1 & 4 & 0 & 0 & \multirow{3}{*}{ up } & \multirow{3}{*}[60]{} \\
\hline & & LOC_Os03g15770.2 & 1 & 1 & 0 & & \\
\hline & & LOC_Os03g15770.3 & 5 & 0 & 0 & & \\
\hline $\begin{array}{l}\text { RLCK110 } \\
\text { (PTK5) }\end{array}$ & Os03g0407900 & LOC_Os03g29410.1 & 2 & 0 & 0 & up & {$[60]$} \\
\hline$R L C K 167$ & Os04g0654600 & LOC_Os04g56060.1 & 3 & 0 & 0 & down & [60] \\
\hline \multirow{3}{*}{$R L C K 168$} & \multirow{3}{*}{ Os04g0655300 } & LOC_Os04g56110.1 & 6 & 0 & 0 & \multirow{3}{*}{ up } & \multirow{3}{*}[60]{} \\
\hline & & LOC_Os04g56110.2 & 23 & 0 & 0 & & \\
\hline & & LOC_Os04g56110.3 & 5 & 0 & 0 & & \\
\hline \multirow{2}{*}{ RLCK191 } & \multirow[b]{2}{*}{ Os05g0589700 } & LOC_Os05g51190.2 & 1 & 0 & 0 & \multirow{2}{*}{ down } & \multirow[b]{2}{*}[60]{} \\
\hline & & LOC_Os05g51190.3 & 1 & 0 & 0 & & \\
\hline $\begin{array}{l}\text { RLCK194 } \\
\text { (PUB5) }\end{array}$ & Os06g0140800 & LOC_Os06g04880.1 & 2 & 0 & 0 & up & {$[60]$} \\
\hline RLCK204 & Os06g0203800 & LOC_Os06g10230.1 & 1 & 1 & 0 & down & [60] \\
\hline $\begin{array}{c}\text { RLCK216 } \\
(R R K 1)\end{array}$ & Os06g0693200 & LOC_Os06g47820.1 & 1 & 0 & 0 & up & {$[60]$} \\
\hline$R L C K 218$ & Os06g0714900 & LOC_Os06g50100.1 & 6 & 0 & 0 & up & {$[60]$} \\
\hline$R L C K 223$ & Os07g0159700 & LOC_Os07g06570.1 & 1 & 0 & 0 & down & {$[60]$} \\
\hline$R L C K 242$ & Os07g0693000 & LOC_Os07g49240.1 & 1 & 0 & 0 & down & {$[60]$} \\
\hline $\begin{array}{l}\text { RLCK249 } \\
\text { (ER1) }\end{array}$ & Os06g0203800 & LOC_Os06g10230.1 & 1 & 1 & 0 & down & {$[60]$} \\
\hline & & LOC_Os10g30600.1 & 1 & 0 & 0 & & \\
\hline RLCK301 & Os10g0442800 & LOC_Os10g30600.2 & 5 & 0 & 0 & up & {$[60]$} \\
\hline$R L C K 334$ & Os11g0556400 & LOC_Os11g35274.1 & 1 & 0 & 0 & down & {$[60]$} \\
\hline & & LOC_Os12g41710.1 & 4 & 0 & 0 & & \\
\hline & & LOC_Os12g41710.2 & 30 & 0 & 0 & & \\
\hline RLCK373 & Us12g0611100 & LOC_Os12g41710.3 & 16 & 0 & 0 & down & [60] \\
\hline & & LOC_Os12g41710.4 & 29 & 0 & 0 & & \\
\hline$R L C K 375$ & Os12g0615300 & LOC_Os12g42070.1 & 7 & 0 & 0 & down & {$[60]$} \\
\hline Aldh2a & Os02g0730000 & LOC_Os02g49720.6 & 7 & 1 & 0 & up & {$[61]$} \\
\hline$A B A 2$ & Os03g0810800 & LOC_Os03g59610.1 & 1 & 0 & 0 & up & [55] \\
\hline
\end{tabular}


(A)

Normal condition

Alterntive splicing
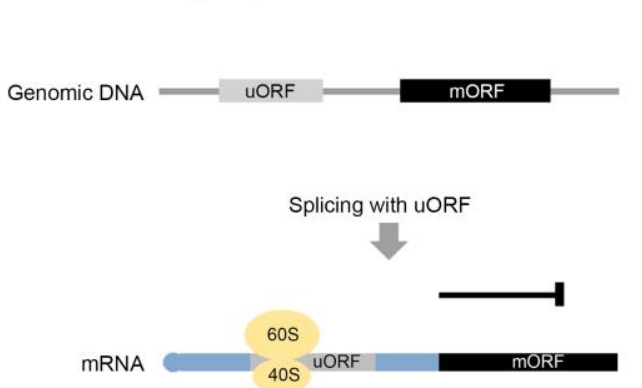

(B)

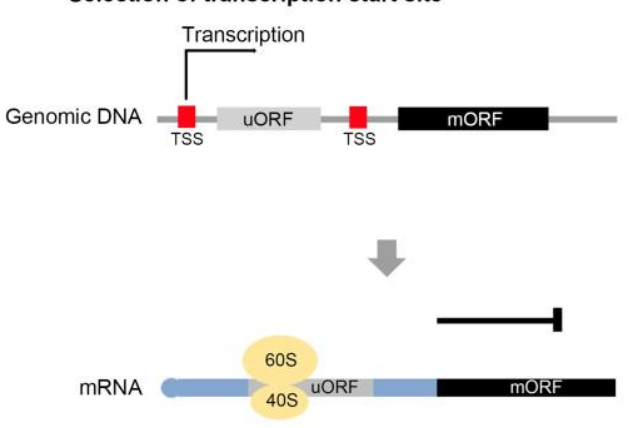

Stress condition . 
2019, herbicide tolerance and insect resistance were the principal target traits, but a more recent focus has been on the development of stacked traits, including increased yield and tolerance to abiotic and biotic stresses. The cultivation area of GM crops with stacked traits increased from 58.5 million hectares in 2015 to 85.1 million hectares in 2019 [73].

Since the development of the first GM crops, a variety of genes and hormone regulated pathways that affect plant stress response have been identified, and GM crops have been developed to improve traits such as yield and tolerance to abiotic stresses, including drought and high salinity [74]. Thus, elucidation of the molecular mechanisms of hormone biosynthesis and signaling pathways are providing new genes to target for developing GE crops $[7,8]$.

\subsection{Hormone Regulation in Plant Salt Stress Response}

Many details of the molecular mechanisms by which the phytohormones abscisic acid $(\mathrm{ABA})$ and JA regulate salt and drought stress responses have been uncovered. It has been shown that JA signal transduction is propagated by the degradation of the jasmonate ZIM domain (JAZ) repressor proteins. This degradation allows transcription factors (TFs) to bind to the promoter of JA response genes, which include salt-responsive genes, inducing their transcription $[75,76]$. As an example, it was reported that, in rice, OsJAZ9 regulates transcription of the TF OsbHLH062, which is involved in salt stress tolerance in rice [57]. ABA belongs to a class of metabolites known as isoprenoids, also called terpenoids [77], and conjugated forms of ABA play an important role in ABA homeostasis. Examples include phaseic acid, a catabolite of ABA that is generated through the action of an $A B A 8^{\prime}$-hydroxylase (ABA8ox), and an inactivated glucose-conjugated form, mediated by ABA glucosyltransferase (AOG). Accordingly, loss of function mutants of $A B A 80 x$ accumulate more ABA than transgenic Arabidopsis plants overexpressing ABA biosynthetic genes [78]. Under salt stress conditions, ABA concentrations in rice are significantly higher, and the expression of ABA biosynthesis genes, including OsABA2 and $O s A A O 3$, is induced [55]. Genes involved in regulating ABA levels are therefore of interest as targets for the development of salt-tolerant crops. Moreover, ion homeostasis in the cell is essential for tolerance to salt stress, and high-affinity potassium transporters (HKTs), $\mathrm{Na}+/ \mathrm{H}+$ exchangers (NHXs), and salt overly sensitive (SOS) have all been shown to regulate salt stress tolerance in the plant through the balance of intracellular sodium levels $[79,80]$. Knowledge of these hormone synthesis pathways and salt stress signaling pathways has guided the utilization of plant genetic engineering tools for improving salt stress resistance in crops.

\section{Enhancing Gene Expression in Crops by Editing uORFs Using the CRISPR System as an Alternative to GM Approaches}

Over the last few decades, GM crops have been developed based on the functional study of individual genes. However, the average time and cost for developing GM crops is 13 years and $\$ 130$ million, respectively, and in many countries, regulatory obstacles still block the commercial cultivation of GM crops [81]. Recently, GE technology, which involves the precise modification of the target genome locus, has enabled the development of bio-engineered crops at a lower cost and in a shorter time period [82,83]. However, this approach has inherent limitations in terms of target gene selection compared to GM technology. GM technology was applied for both overexpression and repression of the target genes. However, GE technology has mainly been applied so far for generating the mutants of target genes by mutation and deletion. Here, we highlight the potential for editing uORFs using GE technology to enhance the expression of target genes associated with various crop traits, thereby expanding the scope of target gene selection and allowing for precise control of target gene expression. For example, editing of the uORF of LsGGP2, which encodes an enzyme involved in vitamin C biosynthesis, using the CRISPR-Cas 9 system conferred enhanced oxidative stress tolerance and elevated ascorbate levels [84]. In addition, editing the conserved uORF of FvebZIP1.1, which fine-tunes carbon-nitrogen metabolism, resulted in enhanced sugar content in strawberries compared to wild-type [85] 
Generally, elevated expression of stress-related genes inhibits plant growth due to the tradeoff between growth and defense. For example, overexpression of AtJMT in rice led to drought tolerance but decreased growth and yield [86]. Many salt stress-responsive genes, including HAK1, NHX1, SOS1, IDS1, NAC6, EIL2, bHLH035, JAZ9, RSS3, ACA6, and $A B A 2$ (Table 1), have been identified and functionally characterized by transgenic research. The editing of uORFs in crops using GE technology to target such genes with a verified function associated with stress resistance would be expected to save time and incur less financial cost than traditional breeding or GM approaches, and this strategy is of growing interest [87].

We summarize the process of gene editing of $\mathrm{uORF}$ with the CRISPR system for the development of GE crops (Figure 4): (1) screening mutants or genes for improving the crop traits of interest, such as salt stress-resistance; (2) investigating the gene function and traits, then isolating the candidate genes; (3) analysis and prediction of uORFs in the 5'UTR of the selected gene; (4) investigating the predicted uORFs using a dual-luciferase assay in protoplasts; (5) constructing a CRISPR vector for targeting uORFs and generating the uORF mutant; (6) assessing altered expression of the target gene by uORF mutation and selecting the homozygous mutants without transgene by genotyping; and (7) characterizing the GE crop traits under field conditions.
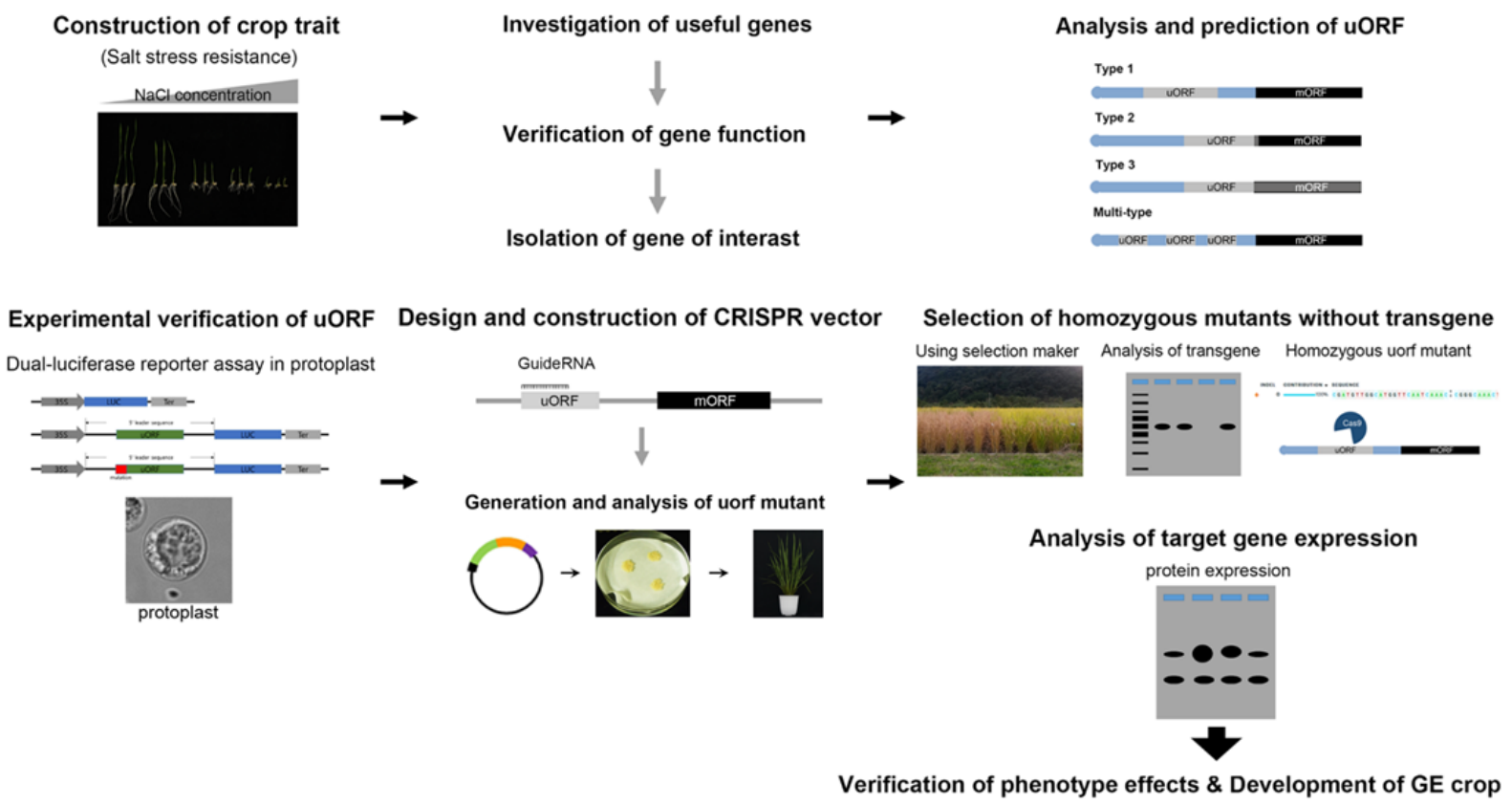

Figure 4. Overview of the process of gene editing of uORFs with the CRISPR system for the development of GE crops.

\section{Future Prospects}

A second 'green revolution' is required to support the growing global population and to mitigate negative environmental impacts. To develop biotech crops, it is necessary to identify genes' underlying quality traits involved in plant defense and growth. The function of stress-responsive genes has been long been characterized in plants using transgenic plant technologies, and recent GE technologies, such as CRISPR and TALEN, are becoming increasingly widespread. The application of uORF mutations via GE has great potential to expand the diversity and global market of GE crops, and will likely be an important factor in stabilizing the food supply and supporting future sustainable agricultural systems.

Author Contributions: Conceptualization, T.U., J.S.S. (Jun Sung Seo), and S.C.P.; investigation, T.U., J.S.S. (Jun Sung Seo), T.P., J.S.S. (Jae Sung Shim), Y.S.K., G.-S.L., I.-Y.C., J.-K.K., and S.C.P.; writingoriginal draft preparation, T.U.; writing-review and editing, J.S.S. (Jun Sung Seo); visualization, 
T.U.; funding acquition, S.C.P. All authors have read and agreed to the published version of the manuscript.

Funding: This research was funded by a grant from the New Breeding Technologies Development Program (Project No. PJ01479303), Rural Development Administration, Republic of Korea.

Acknowledgments: We are thankful to an anonymous reviewer for their comments and critical reading of the manuscript.

Conflicts of Interest: All authors declare that there is no conflict of interest.

\section{References}

1. Zhao, C.; Liu, B.; Piao, S.; Wang, X.; Lobell, D.B.; Huang, Y.; Huang, M.; Yao, Y.; Bassu, S.; Ciais, P.; et al. Temperature increase reduces global yields of major crops in four independent estimates. Proc. Natl. Acad. Sci. USA 2017, 114, 9326-9331. [CrossRef]

2. d'Amour, C.B.; Reitsma, F.; Baiocchi, G.; Barthel, S.; Güneralp, B.; Erb, K.-H.; Haberl, H.; Creutzig, F.; Seto, K.C. Future urban land expansion and implications for global croplands. Proc. Natl. Acad. Sci. USA 2017, 114, 8939-8944. [CrossRef] [PubMed]

3. Ray, D.K.; Mueller, N.D.; West, P.C.; Foley, J.A. Yield trends are insufficient to double global crop production by 2050. PLoS ONE 2013, 8, e66428. [CrossRef] [PubMed]

4. Röös, E.; Bajželj, B.; Smith, P.; Patel, M.; Little, D.; Garnett, T. Greedy or needy? Land use and climate impacts of food in 2050 under different livestock futures. Glob. Environ. Chang. 2017, 47, 1-12. [CrossRef]

5. Kamthan, A.; Chaudhuri, A.; Kamthan, M.; Datta, A. Genetically modified (GM) crops: Milestones and new advances in crop improvement. Theor. Appl. Genet. 2016, 129, 1639-1655. [CrossRef]

6. Sakamoto, T. Phytohormones and rice crop yield: Strategies and opportunities for genetic improvement. Transgenic Res. 2006, 15, 399-404. [CrossRef]

7. McSteen, P.; Zhao, Y. Plant hormones and signaling: Common themes and new developments. Dev. Cell 2008, 14, 467-473. [CrossRef] [PubMed]

8. Spartz, A.K.; Gray, W.M. Plant hormone receptors: New perceptions. Genes Dev. 2008, 22, 2139-2148. [CrossRef]

9. Gaj, T.; Gersbach, C.A.; Barbas, C.F., III. ZFN, TALEN, and CRISPR/Cas-based methods for genome engineering. Trends Biotechnol. 2013, 31, 397-405. [CrossRef]

10. Calyxt Inc. First Commercial Sale of Calyxt High Oleic Soybean Oil on the U.S. Market; Calyxt Inc.: St. Paul, MN, USA, 2019; Available online: https:/ / calyxt.com/ first-commercial-sale-of-calyxt-high-oleic-soybean-oil-on-the-u-s-market (accessed on 26 February 2019).

11. Sikora, P.; Chawade, A.; Larsson, M.; Olsson, J.; Olsson, O. Mutagenesis as a tool in plant genetics, functional genomics, and breeding. Int. J. Plant Genom. 2011, 2011, 314829. [CrossRef]

12. Grohmann, L.; Keilwagen, J.; Duensing, N.; Dagand, E.; Hartung, F.; Wilhelm, R.; Bendiek, J.; Sprink, T. Detection and identification of genome editing in plants: Challenges and opportunities. Front. Plant Sci. 2019, 10, 236. [CrossRef] [PubMed]

13. Menz, J.; Modrzejewski, D.; Hartung, F.; Wilhelm, R.; Sprink, T. Genome edited crops touch the market: A view on the global development and regulatory environment. Front. Plant Sci. 2020, 11, 586027. [CrossRef] [PubMed]

14. Kurihara, Y. uORF Shuffling Fine-Tunes Gene Expression at a Deep Level of the Process. Plants 2020, 9, 608. [CrossRef]

15. Morris, D.R.; Geballe, A.P. Upstream open reading frames as regulators of mRNA translation. Mol. Cell. Biol. 2000, 20, 8635-8642. [CrossRef]

16. Bazin, J.; Baerenfaller, K.; Gosai, S.J.; Gregory, B.D.; Crespi, M.; Bailey-Serres, J. Global analysis of ribosome-associated noncoding RNAs unveils new modes of translational regulation. Proc. Natl. Acad. Sci. USA 2017, 114, E10018-E10027. [CrossRef] [PubMed]

17. Calvo, S.E.; Pagliarini, D.J.; Mootha, V.K. Upstream open reading frames cause widespread reduction of protein expression and are polymorphic among humans. Proc. Natl. Acad. Sci. USA 2009, 106, 7507-7512. [CrossRef]

18. Von Arnim, A.G.; Jia, Q.; Vaughn, J.N. Regulation of plant translation by upstream open reading frames. Plant Sci. 2014, 214, 1-12. [CrossRef] [PubMed]

19. Ebina, I.; Takemoto-Tsutsumi, M.; Watanabe, S.; Koyama, H.; Endo, Y.; Kimata, K.; Igarashi, T.; Murakami, K.; Kudo, R.; Ohsumi, A. Identification of novel Arabidopsis thaliana upstream open reading frames that control expression of the main coding sequences in a peptide sequence-dependent manner. Nucleic Acids Res. 2015, 43, 1562-1576. [CrossRef]

20. Hayashi, N.; Sasaki, S.; Takahashi, H.; Yamashita, Y.; Naito, S.; Onouchi, H. Identification of Arabidopsis thaliana upstream open reading frames encoding peptide sequences that cause ribosomal arrest. Nucleic Acids Res. 2017, 45, 8844-8858. [CrossRef]

21. Barbosa, C.; Peixeiro, I.; Romão, L. Gene expression regulation by upstream open reading frames and human disease. PLoS Genet. 2013, 9, e1003529. [CrossRef]

22. Wittmann, J.; Hol, E.M.; Jäck, H.-M. hUPF2 silencing identifies physiologic substrates of mammalian nonsense-mediated mRNA decay. Mol. Cell. Biol. 2006, 26, 1272-1287. [CrossRef]

23. Yepiskoposyan, H.; Aeschimann, F.; Nilsson, D.; Okoniewski, M.; Mühlemann, O. Autoregulation of the nonsense-mediated mRNA decay pathway in human cells. RNA 2011, 17, 2108-2118. [CrossRef] [PubMed]

24. Spriggs, K.A.; Bushell, M.; Willis, A.E. Translational regulation of gene expression during conditions of cell stress. Mol. Cell 2010, 40, 228-237. [CrossRef] 
25. Niu, R.; Zhou, Y.; Zhang, Y.; Mou, R.; Tang, Z.; Wang, Z.; Zhou, G.; Guo, S.; Yuan, M.; Xu, G. uORFlight: A vehicle toward uORF-mediated translational regulation mechanisms in eukaryotes. Database (Oxford) 2020, 2020. [CrossRef] [PubMed]

26. Mittler, R. Abiotic stress, the field environment and stress combination. Trends Plant Sci. 2006, 11, 15-19. [CrossRef] [PubMed]

27. Peet, M.; Kramer, P. Effects of decreasing source/sink ratio in soybeans on photosynthesis, photorespiration, transpiration and yield. Plant Cell Environ. 1980, 3, 201-206.

28. Munns, R. Comparative physiology of salt and water stress. Plant Cell Environ. 2002, 25, 239-250. [CrossRef] [PubMed]

29. Bartels, D.; Sunkar, R. Drought and salt tolerance in plants. Crit. Rev. Plant Sci. 2005, 24, 23-58. [CrossRef]

30. Verslues, P.E.; Agarwal, M.; Katiyar-Agarwal, S.; Zhu, J.; Zhu, J.K. Methods and concepts in quantifying resistance to drought, salt and freezing, abiotic stresses that affect plant water status. Plant J. 2006, 45, 523-539. [CrossRef] [PubMed]

31. Wellman, C.H.; Gray, J. The microfossil record of early land plants. Philos. Trans. R. Soc. B Biol. Sci. 2000, 355, 717-732. [CrossRef]

32. Wellman, C.H.; Osterloff, P.L.; Mohiuddin, U. Fragments of the earliest land plants. Nature 2003, 425, 282. [CrossRef] [PubMed]

33. Eckardt, N.A. Sequencing the rice genome. Am. Soc. Plant Biol. 2000. [CrossRef]

34. Fairhurst, T.; Dobermann, A. Rice in the global food supply. World 2002, 5, 454, 349-511, 675.

35. Mindell, J.; Maduke, M. ClC chloride channels. Genome Biol. 2001, 2, reviews3003.1. [CrossRef] [PubMed]

36. Jentsch, T.J. CLC chloride channels and transporters: From genes to protein structure, pathology and physiology. Crit. Rev. Biochem. Mol. Biol. 2008, 43, 3-36. [CrossRef] [PubMed]

37. Nakamura, A.; Fukuda, A.; Sakai, S.; Tanaka, Y. Molecular cloning, functional expression and subcellular localization of two putative vacuolar voltage-gated chloride channels in rice (Oryza sativa L.). Plant Cell Physiol. 2006, 47, 32-42. [CrossRef]

38. Um, T.Y.; Lee, S.; Kim, J.-K.; Jang, G.; Do Choi, Y. CHLORIDE CHANNEL 1 promotes drought tolerance in rice, leading to increased grain yield. Plant Biotechnol. Rep. 2018, 12, 283-293. [CrossRef]

39. Huot, B.; Yao, J.; Montgomery, B.L.; He, S.Y. Growth-defense tradeoffs in plants: A balancing act to optimize fitness. Mol. Plant 2014, 7, 1267-1287. [CrossRef]

40. Züst, T.; Agrawal, A.A. Trade-offs between plant growth and defense against insect herbivory: An emerging mechanistic synthesis. Annu. Rev. Plant Biol. 2017, 68, 513-534. [CrossRef]

41. Hou, X.; Ding, L.; Yu, H. Crosstalk between GA and JA signaling mediates plant growth and defense. Plant Cell Rep. 2013, 32, 1067-1074. [CrossRef]

42. Yang, D.-L.; Yao, J.; Mei, C.-S.; Tong, X.-H.; Zeng, L.-J.; Li, Q.; Xiao, L.-T.; Sun, T.-P.; Li, J.; Deng, X.-W. Plant hormone jasmonate prioritizes defense over growth by interfering with gibberellin signaling cascade. Proc. Natl. Acad. Sci. USA 2012, 109, E1192-E1200. [CrossRef]

43. Um, T.Y.; Lee, H.Y.; Lee, S.; Chang, S.H.; Chung, P.J.; Oh, K.-B.; Kim, J.-K.; Jang, G.; Choi, Y.D. JASMONATE ZIM-DOMAIN PROTEIN 9 interacts with SLENDER RICE 1 to mediate the antagonistic interaction between jasmonic and gibberellic acid signals in rice. Front. Plant Sci. 2018, 9, 1866. [CrossRef]

44. van der Horst, S.; Filipovska, T.; Hanson, J.; Smeekens, S. Metabolite control of translation by conserved peptide uORFs: The ribosome as a metabolite multisensor. Plant Physiol. 2020, 182, 110-122. [CrossRef] [PubMed]

45. Kozak, M. Effects of intercistronic length on the efficiency of reinitiation by eucaryotic ribosomes. Mol. Cell. Biol. 1987, 7, 3438-3445. [CrossRef] [PubMed]

46. Srivastava, A.K.; Lu, Y.; Zinta, G.; Lang, Z.; Zhu, J.-K. UTR-dependent control of gene expression in plants. Trends Plant Sci. 2018, 23, 248-259. [CrossRef]

47. Tokizawa, M.; Kusunoki, K.; Koyama, H.; Kurotani, A.; Sakurai, T.; Suzuki, Y.; Sakamoto, T.; Kurata, T.; Yamamoto, Y.Y. Identification of Arabidopsis genic and non-genic promoters by paired-end sequencing of TSS tags. Plant J. 2017, 90, 587-605. [CrossRef]

48. Chen, G.; Hu, Q.; Luo, L.; Yang, T.; Zhang, S.; Hu, Y.; Yu, L.; Xu, G. Rice potassium transporter O s HAK 1 is essential for maintaining potassium-mediated growth and functions in salt tolerance over low and high potassium concentration ranges. Plant Cell Environ. 2015, 38, 2747-2765. [CrossRef]

49. Wang, H.; Zhang, M.; Guo, R.; Shi, D.; Liu, B.; Lin, X.; Yang, C. Effects of salt stress on ion balance and nitrogen metabolism of old and young leaves in rice (Oryza sativa L.). BMC Plant Biol. 2012, 12, 1-11. [CrossRef] [PubMed]

50. Hossain, M.M.; Imran, S.; Islam, M.A.; Abdul, M. Expressional analysis of OsNHX1, OsNHX2, OsSOS1 and Os DREB transporters in salt tolerant (FR13A) and salt sensitive rice (brri dhan29) induced by salinity stress. IOSR J. Agric. Vet. Sci. 2017, 10, 64-70.

51. Yamada, N.; Theerawitaya, C.; Cha-um, S.; Kirdmanee, C.; Takabe, T. Expression and functional analysis of putative vacuolar Ca 2+-transporters (CAXs and ACAs) in roots of salt tolerant and sensitive rice cultivars. Protoplasma 2014, 251, 1067-1075. [CrossRef] [PubMed]

52. Cheng, X.; Zhang, S.; Tao, W.; Zhang, X.; Liu, J.; Sun, J.; Zhang, H.; Pu, L.; Huang, R.; Chen, T. INDETERMINATE SPIKELET1 recruits histone deacetylase and a transcriptional repression complex to regulate rice salt tolerance. Plant Physiol. 2018, 178, 824-837. [CrossRef] [PubMed]

53. Nakashima, K.; Tran, L.S.P.; Van Nguyen, D.; Fujita, M.; Maruyama, K.; Todaka, D.; Ito, Y.; Hayashi, N.; Shinozaki, K.; YamaguchiShinozaki, K. Functional analysis of a NAC-type transcription factor OsNAC6 involved in abiotic and biotic stress-responsive gene expression in rice. Plant J. 2007, 51, 617-630. [CrossRef] 
54. Yang, C.; Ma, B.; He, S.-J.; Xiong, Q.; Duan, K.-X.; Yin, C.-C.; Chen, H.; Lu, X.; Chen, S.-Y.; Zhang, J.-S. MAOHUZI6/ETHYLENE INSENSITIVE3-LIKE1 and ETHYLENE INSENSITIVE3-LIKE2 regulate ethylene response of roots and coleoptiles and negatively affect salt tolerance in rice. Plant Physiol. 2015, 169, 148-165. [CrossRef]

55. Chen, H.-C.; Cheng, W.-H.; Hong, C.-Y.; Chang, Y.-S.; Chang, M.-C. The transcription factor OsbHLH035 mediates seed germination and enables seedling recovery from salt stress through ABA-dependent and ABA-independent pathways, respectively. Rice 2018, 11, 1-17. [CrossRef] [PubMed]

56. Wang, X.-S.; Zhu, H.-B.; Jin, G.-L.; Liu, H.-L.; Wu, W.-R.; Zhu, J. Genome-scale identification and analysis of LEA genes in rice (Oryza sativa L.). Plant Sci. 2007, 172, 414-420. [CrossRef]

57. Wu, H.; Ye, H.; Yao, R.; Zhang, T.; Xiong, L. OsJAZ9 acts as a transcriptional regulator in jasmonate signaling and modulates salt stress tolerance in rice. Plant Sci. 2015, 232,1-12. [CrossRef]

58. Toda, Y.; Tanaka, M.; Ogawa, D.; Kurata, K.; Kurotani, K.-I.; Habu, Y.; Ando, T.; Sugimoto, K.; Mitsuda, N.; Katoh, E. RICE SALT SENSITIVE3 forms a ternary complex with JAZ and class-C bHLH factors and regulates jasmonate-induced gene expression and root cell elongation. Plant Cell 2013, 25, 1709-1725. [CrossRef]

59. Huda, K.M.; Banu, M.S.A.; Garg, B.; Tula, S.; Tuteja, R.; Tuteja, N. Os ACA 6, a P-type IIB Ca2+ ATP ase promotes salinity and drought stress tolerance in tobacco by ROS scavenging and enhancing the expression of stress-responsive genes. Plant J. 2013, 76, 997-1015. [CrossRef]

60. Vij, S.; Giri, J.; Dansana, P.K.; Kapoor, S.; Tyagi, A.K. The receptor-like cytoplasmic kinase (OsRLCK) gene family in rice: Organization, phylogenetic relationship, and expression during development and stress. Mol. Plant 2008, 1, 732-750. [CrossRef]

61. Ranawake, A.L.; Mori, N.; Nakamura, C. Expression profiles of stress responsive genes in rice (Oryza sativa L.) under abiotic stresses. Biotechnol. Biotechnol. Equip. 2012, 26, 2838-2843. [CrossRef]

62. Ahmad, P.; Ashraf, M.; Younis, M.; Hu, X.; Kumar, A.; Akram, N.A.; Al-Qurainy, F. Role of transgenic plants in agriculture and biopharming. Biotechnol. Adv. 2012, 30, 524-540. [CrossRef] [PubMed]

63. He, Z.; Xia, X.; Peng, S.; Lumpkin, T.A. Meeting demands for increased cereal production in China. J. Cereal Sci. 2014, 59, 235-244. [CrossRef]

64. Barton, K.A.; Binns, A.N.; Matzke, A.J.; Chilton, M.-D. Regeneration of intact tobacco plants containing full length copies of genetically engineered T-DNA, and transmission of T-DNA to R1 progeny. Cell 1983, 32, 1033-1043. [CrossRef]

65. Gatehouse, J.A. Biotechnological prospects for engineering insect-resistant plants. Plant Physiol. 2008, 146, 881-887. [CrossRef]

66. Herrera-Estrella, L.; Depicker, A.; Van Montagu, M.; Schell, J. Expression of chimaeric genes transferred into plant cells using a Ti-plasmid-derived vector. Nature 1983, 303, 209. [CrossRef]

67. Meinke, D.W.; Cherry, J.M.; Dean, C.; Rounsley, S.D.; Koornneef, M. Arabidopsis thaliana: A model plant for genome analysis. Science 1998, 282, 662-682. [CrossRef]

68. Gordon-Kamm, W.J.; Spencer, T.M.; Mangano, M.L.; Adams, T.R.; Daines, R.J.; Start, W.G.; O’Brien, J.V.; Chambers, S.A.; Adams, W.R.; Willetts, N.G. Transformation of maize cells and regeneration of fertile transgenic plants. Plant Cell 1990, 2, 603-618. [CrossRef]

69. McCabe, D.E.; Swain, W.F.; Martinell, B.J.; Christou, P. Stable transformation of soybean (Glycine max) by particle acceleration. Bio/Technology 1988, 6, 923. [CrossRef]

70. Umbeck, P.; Johnson, G.; Barton, K.; Swain, W. Genetically transformed cotton (Gossypium hirsutum L.) plants. Bio/Technology 1987, 5, 263. [CrossRef]

71. Cerdeira, A.L.; Duke, S.O. The current status and environmental impacts of glyphosate-resistant crops. J. Environ. Qual. 2006, 35, 1633-1658. [CrossRef]

72. Raven, P.H. Does the use of transgenic plants diminish or promote biodiversity? New Biotechnol. 2010, 27, 528-533. [CrossRef] [PubMed]

73. ISAAA. Global Status of Commercialized Biotech/GM Crops in 2019: Biotech Crops Drive Socio-Economic Development and Sustainable Environment in the New Frontier; ISAAA Brief No. 55; ISAAA Ithaca: New York, NY, USA, 2019.

74. Wang, W.; Vinocur, B.; Altman, A. Plant responses to drought, salinity and extreme temperatures: Towards genetic engineering for stress tolerance. Planta 2003, 218, 1-14. [CrossRef]

75. Boter, M.; Ruíz-Rivero, O.; Abdeen, A.; Prat, S. Conserved MYC transcription factors play a key role in jasmonate signaling both in tomato and Arabidopsis. Genes Dev. 2004, 18, 1577-1591. [CrossRef] [PubMed]

76. Seo, J.-S.; Joo, J.; Kim, M.-J.; Kim, Y.-K.; Nahm, B.H.; Song, S.I.; Cheong, J.-J.; Lee, J.S.; Kim, J.-K.; Choi, Y.D. OsbHLH148, a basic helix-loop-helix protein, interacts with OsJAZ proteins in a jasmonate signaling pathway leading to drought tolerance in rice. Plant J. 2011, 65, 907-921. [CrossRef] [PubMed]

77. Nambara, E.; Marion-Poll, A. Abscisic Acid Biosynthesis and Catabolism. Annu. Rev. Plant Biol. 2005, 56, 165-185. [CrossRef]

78. Finkelstein, R. Abscisic Acid synthesis and response. Arab. Book 2013, 11, e0166. [CrossRef] [PubMed]

79. Deinlein, U.; Stephan, A.B.; Horie, T.; Luo, W.; Xu, G.; Schroeder, J.I. Plant salt-tolerance mechanisms. Trends Plant Sci. 2014, 19, 371-379. [CrossRef] [PubMed]

80. Hamamoto, S.; Horie, T.; Hauser, F.; Deinlein, U.; Schroeder, J.I.; Uozumi, N. HKT transporters mediate salt stress resistance in plants: From structure and function to the field. Curr. Opin. Biotechnol. 2015, 32, 113-120. [CrossRef]

81. Le Page, M. The second great food war. New Sci. 2018, 239, 22-23. [CrossRef] 
82. Gaj, T.; Sirk, S.J.; Shui, S.-L.; Liu, J. Genome-editing technologies: Principles and applications. Cold Spring Harb. Perspect. Biol. 2016, 8, a023754. [CrossRef]

83. Ahmar, S.; Saeed, S.; Khan, M.H.U.; Ullah Khan, S.; Mora-Poblete, F.; Kamran, M.; Faheem, A.; Maqsood, A.; Rauf, M.; Saleem, S. A Revolution toward Gene-Editing Technology and Its Application to Crop Improvement. Int. J. Mol. Sci. 2020, $21,5665$. [CrossRef] [PubMed]

84. Zhang, H.; Si, X.; Ji, X.; Fan, R.; Liu, J.; Chen, K.; Wang, D.; Gao, C. Genome editing of upstream open reading frames enables translational control in plants. Nat. Biotechnol. 2018, 36, 894-898. [CrossRef] [PubMed]

85. Xing, S.; Chen, K.; Zhu, H.; Zhang, R.; Zhang, H.; Li, B.; Gao, C. Fine-tuning sugar content in strawberry. BMC Genome Biol. 2020, $21,230$.

86. Kim, E.H.; Kim, Y.S.; Park, S.-H.; Koo, Y.J.; Do Choi, Y.; Chung, Y.-Y.; Lee, I.-J.; Kim, J.-K. Methyl jasmonate reduces grain yield by mediating stress signals to alter spikelet development in rice. Plant Physiol. 2009, 149, 1751-1760. [CrossRef]

87. Si, X.; Zhang, H.; Wang, Y.; Chen, K.; Gao, C. Manipulating gene translation in plants by CRISPR-Cas9-mediated genome editing of upstream open reading frames. Nat. Protoc. 2020, 15, 338-363. [CrossRef] [PubMed] 